\title{
Moralidade e justiça na historiografia antiga: o 'manual' historiográfico de Luciano de Samósata
}

\author{
André LEME LOPES*
}

\begin{abstract}
RESUmO: Como se deve escrever a história, de Luciano de Samósata, é o único tratado da Antigüidade sobre historiografia que chegou até nós. Foi escrito no contexto da produção "histórica" gerada pelas guerras párticas de Lucio Vero (segunda metade do século II d.C.). Para ressaltar a dupla posição política e moral do historiador - que deve, acima de tudo, ser justo -, Luciano critica duramente essas narrativas aduladoras e apresenta Tucídides como o historiador ideal.
\end{abstract}

PALAVRAS-CHAVE: historiografia grega; teoria da história; Luciano de Samósata

$\mathrm{Na}$ Antigüidade se inventou a história, e foi pródiga em produções historiográficas, bastante econômica em reflexões sobre essa novidade. Se existem referências a algumas obras antigas que parecem tratar da historiografia - como, por exemplo, o tratado de Teofrasto, Perì Historías (Sobre a história), do qual conhecemos apenas o título, ou o livro de Praxífanes citado por Amiano M arcelino em sua Vida de Tucídides -, essas obras estão hoje completamente perdidas e especular sobre seu conteúdo seria perda de tempo. Aliás, é significativo que nenhuma obra sobre a história seja citada nas bibliografias dadas por Diógenes Laércio em Vidas e doutrinas dos filósofos ilustres.

0 silêncio dos filósofos antigos sobre a historiografia é quase completo. Mesmo Aristóteles, tão prolífico a respeito de todos os campos do conhecimento, a ignora em toda a sua extensa obra. As únicas aparições da história no extenso corpus do filósofo de Estagira são duas passagens da Poética, nas quais é rejeitada em favor da poesia, e uma breve recomendação, na 
Retórica, aos políticos que leiam história para ampliar seus conhecimentos.

Encontramos algumas reflexões sobre a historiografia nas obras dos próprios historiadores. M as, na maior parte das vezes, essas reflexões são fragmentárias, estão inseridas em polêmicas com outros historiadores ou trata-se de simples elogios retóricos da historiografia. Na verdade, a mais completa investigação antiga sobre a historiografia encontra-se em um pequeno tratado da autoria de Luciano de Samósata, um escritor satírico nascido na Síria no século II da Era Cristã: Como se deve escrever a história, a única obra antiga inteiramente dedicada à historiografia de um ponto de vista teórico que conhecemos.

Comecemos, portanto, pelo próprio ineditismo da obra: por que Luciano resolveu escrever uma teoria da história? Por que escrever um tratado que nenhum outro escritor da Antigüidade tivera necessidade ou interesse em escrever?

Encontramos a resposta no próprio texto de Luciano, pois o tratado se inicia com uma anedota: no tempo do rei Lisímaco os cidadãos de Abdera, acometidos por uma febre, saíram às ruas recitando versos da Andrômeda de Eurípides, achando que estavam representando tragédias. Segue-se a crítica: da mesma maneira, um páthos (paixão, doença) havia acometido os intelectuais de seu tempo. "Desde que a situação atual se apresentou - a guerra contra os bárbaros, o desastre na Armênia e a série de vitórias - não há pessoa que não escreva história; mais, todos se tornaram Tucídides, Heródotos e Xenofontes." Luciano acusava os intelectuais gregos de estarem doentes: escreviam e recitavam relatos sobre a guerra contra os partos achando que estavam fazendo história.

Como se deve escrever a história, além de um "manual metodológico", é um "panfleto literário", ou seja, uma obra destinada à crítica de uma prática literária que Luciano não via com bons olhos. Dos 63 parágrafos do texto, Luciano dedica 19, quase um terço da obra, a exemplos de maus historiadores ( $\S \S$ 14-32). Essa mesma técnica, "como não fazer" (crítica cômica) e "como fazer" (preceitos sérios), foi usada por ele em diversos outros panfletos do mesmo tipo como, por exemplo, em M estre de retórica - "como não ser bem-sucedido na retórica e como sê- 
Io" - e em Lexífanes - "como não reviver palavras áticas e como fazê-lo". No entanto, Como se deve escrever a história se destaca dentre todos, pois apenas nele a caricatura não é a principal preocupação do texto e "a balança é mais ou menos equilibrada": ${ }^{2}$ contrapondo-se aos 19 parágrafos dedicados à crítica cômica dos maus historiadores, 27 são destinados aos ensinamentos prescritivos sobre a história ( $\$ \S 34-60$ ).

Sendo uma obra de crítica, Como se deve escrever a história estava, portanto, vivamente inserida na prática historiográfica do século II d.C.. O que não significa necessariamente que os vários exemplos ridículos de histórias e historiadores citados por Luciano tenham realmente existido. Supor que um panfleto crítico possa nos fornecer dados biográficos ou históricos inteiramente confiáveis seria prova de ingenuidade: um panfleto de Luciano é uma obra agonística, de guerra; nele, o verdadeiro só aparece na medida em que um escrito polêmico tem necessidade de coincidir, às vezes, com a verdade. 0 próprio Luciano parece extremamente irônico ao garantir a veracidade das histórias por ele criticadas:

Dir-Ihes-ei então, em detalhes, o quanto me lembro haver ouvido alguns historiadores dizerem recentemente na Jônia, e agora mesmo na Acaia, descrevendo essa mesma guerra. E, em nome das Graças, que ninguém deixe de acreditar no que vou dizer. Pois eu juraria por sua veracidade, se fosse próprio inserir um juramento em um tratado. ${ }^{3}$

É provável que diversos historiadores estivessem ativos na época em que Luciano escreveu e que novas histórias da guerra entre os romanos e os partos fossem publicadas - ou recitadas com freqüência. Já no séc. I a.C., Dionísio de Halicarnasso dizia que o dia não era longo o suficiente para recitar os nomes de todos os historiadores, e decerto um evento como a guerra com o império parto teria tido um efeito impulsionador na produção de obras históricas. No entanto, nada impede que Luciano tivesse criado histórias e historiadores "ideais", que se encaixassem melhor nos pontos que ele critica. A crítica aos maus historiadores se mantém, mesmo que todos os historiadores criticados sejam criação do crítico. 
E a crítica é necessária, pois o que Luciano busca é uma história justa (historías dikaías). A verdade, um dos traços mais importantes da historiografia desde o seu início na Grécia, em Luciano não é senão o instrumento que conduz ao justo. "É necessário" escrever a história "com o verdadeiro": "eis sua régua e seu fio de prumo para uma história justa".

Contudo, se o objetivo de uma história verdadeira é o justo, o historiador deve certamente julgar, não como os juízes que examinam um fato passado para dar-lhe uma solução do presente, mas como uma espécie de juiz que, fazendo a história do presente, deposite suas esperanças no futuro. Pois o presente trazia um complicador: o imperium, o poder militar invencível de Roma. A crítica, assim, ultrapassava os maus historiadores e atingia o poder universal do Império Romano.

Para Luciano, o poder romano era uma constatação evidente e explícita: ninguém se atreveria a combatê-lo, pois ele já havia submetido e conquistado todos os povos. Com efeito, a época da vida de Luciano, o século II d.C., foi o auge do poderio imperial romano, o período dos Antoninos, e a dificuldade de se escrever uma história justa era que a maioria dos historiadores, "negligenciando contar o que ocorreu [os eventos], gastam seu tempo no elogio dos chefes e dos generais, elevando os nossos até as nuvens e depreciando os do inimigo além de toda a medida". ${ }^{5}$

Tratava-se, portanto, de mais do que um panfleto literário. Como se deve escrever a história era, também, um panfleto antiromano. E a crítica era feita em um campo que, para a maior parte dos antigos, era naturalmente político, a historiografia:

[...] como o judeu Flávio Josefo traduziu a história da guerra judaica em grego para formar um contraste com o florescimento da mentirosa historiografia filo-romana, assim - mais ou menos um século mais tarde - o sírio Luciano reagiu com o opúsculo Como se deve escrever a história na ocasião da explosão de uma historiografia filo-romana que floresceu a partir da euforia provocada pelas vitórias de Lúcio Vero. ${ }^{6}$

Luciano:

Com efeito, a crítica de Josefo segue a mesma linha de 
Enquanto aqueles que não estavam próximos às ações coletaram narrativas discordantes e sem propósito tomando por base o que ouviram falar e as escreveram de maneira sofística; e aqueles que estavam presentes, devido à adulação [kolakeía] dos romanos ou ao ódio pelos judeus, mentiram sobre os feitos; e em toda sua obra há, em alguns lugares acusações, em outros elogios; em lugar nenhum há o rigor histórico [akribès tês historías].

Luciano, embora não critique os romanos diretamente nem uma vez, resume seus preceitos para a história dizendo que é necessário escrever a história "com o verdadeiro [...] mais do que com a adulação [kolakeía]". ${ }^{8}$ Portanto, 0 alvo das críticas de ambos eram os historiadores aduladores, intelectuais que estavam mais preocupados com os favores dos poderosos do que com a narrativa dos eventos ou com o rigor histórico, as preocupações de um verdadeiro historiador. Além disso, ao escrever em grego, ambos os autores visavam, evidentemente, a um público que falava grego e, certamente, suas críticas eram dirigidas aos historiadores que escreveram histórias romanas em grego. Ora, qual seria a relação possível entre esses intelectuais gregos e seus senhores romanos senão a adulação e a troca de favores?

Podemos ler, assim, em Luciano, uma forte oposição entre a verdade que a história deveria possuir e a adulação que, na maior parte dos casos, era o que se lia nas narrativas dos historiadores. A oposição central do Como se deve escrever a história não é, portanto, entre verdade e mentira, como poderíamos pensar inicialmente; é entre verdade e adulação, pois a história era um assunto político que exigia imparcialidade e justiça.

Ao contrário de Flávio Josefo, que ofereceu sua própria versão dos fatos contra as histórias aduladoras dos filo-romanos, Luciano ofereceu apenas "alguns pequenos conselhos e preceitos àqueles que escrevem história". Ele sabia perfeitamente que seus conselhos não seriam bem vistos por muitos historiadores, pois "a maioria deles acha que não precisa de conselhos", ao contrário, acha que "escrever história é uma coisa fácil e simples". Com tudo isso, Luciano sabia que não converteria muitos; mas oferece seus conselhos de qualquer jeito, pois 
[...] se outra guerra ocorrer [...] eles poderão escrever melhor aplicando a régua que lhes ofereço, se ela lhes parece ser acurada. Senão, que continuem a medir sua obra de sua própria maneira, como fazem agora. 0 médico não ficará muito incomodado se todos os abderitas ficarem felizes por representar a Andrômeda. ${ }^{9}$

Nessa passagem, a relação entre a doença dos abderitas que febris achavam que representavam tragédias, e a dos intelectuais, que com seus relatos aduladores achavam que escreviam história - torna-se mais perceptível. Ou melhor, a relação entre seus tratamentos se esclarece. Do mesmo modo que o médico tratava a febre dos abderitas, Luciano oferecia em seus preceitos uma régua para corrigir a "doença" dos maus historiadores; e ele conclui: "se alguns [historiadores] se orientarem por essas [regras e preceitos para se escrever uma história justa], ficará tudo bem e nosso trabalho terá sido aproveitado; senão, estivemos rolando nosso tonel pelo Crânion".

É nessa relação do médico dos abderitas com a doença que acometia os intelectuais que escreviam histórias que podemos entender a aparição de Diógenes no Como se deve escrever a história. Com efeito, ao rolar seu tonel pelo Crânion, o ginásio de Corinto, para não ser o único desocupado na defesa da cidade contra as tropas macedônicas de Filipe II, Diógenes adotara a única ação eficaz quando o poder contra o qual se bate é invencível, a crítica. U ma crítica cômica que desloca as fronteiras entre o sério e o ridículo e que mostra o ridículo de ações pretensamente sérias.

Do mesmo modo, a única ação possível para Luciano contra o poder invencível de Roma e seus aduladores era a crítica. Em diversas obras de Luciano os filósofos cínicos - como Diógenes, Crates, Menipo e outros - são encarregados dessa crítica que, mesmo cômica e caricatural, não perde sua mordacidade. Eles são os médicos das paixões - as doenças da mente humana - e o próprio Luciano, pela boca de Diógenes, nos diz qual a função do crítico cínico: "Sou um libertador de homens e um médico de suas paixões; para dizer tudo, quero ser um profeta da verdade e da franqueza."11 
0 médico das paixões é uma imagem comum na literatura cínica. Com efeito, os cínicos eram seguidores de uma doutrina filosófica que se preocupava exclusivamente com a ética das ações humanas, sustentando que o objetivo supremo dos homens é viver de uma maneira virtuosa, e Crates nos diz, pela pena de Luciano, quais as virtudes que devem ser exercidas: a sabedoria (sophía), a auto-suficiência (autárkeia), a verdade (alétheia), a franqueza (parresía) e a liberdade (eleuthería). Juntas, essas virtudes são bens "muito mais importantes e magníficos que 0 Império Persa". ${ }^{12}$

$\mathrm{Não}$ se pode deixar de observar que quase todas essas virtudes aparecem na definição do historiador ideal em Como se deve escrever a história:

Assim, pois, para mim, deve ser o historiador: sem medo, incorruptível, livre [eleútheros], amigo da franqueza [parresías] e da verdade [alétheias]; como diz o poeta cômico, alguém que chame os figos de figos e a gamela de gamela; alguém que não admita nem omita nada por ódio ou por amizade; que a ninguém poupe, nem respeite, nem humilhe; que seja juiz equânime, benevolente com todos até o ponto de não dar a um mais que o devido; estrangeiro nos livros, sem cidade, independente [autónomos], sem rei, não se preocupando com 0 que achará este ou aquele, mas dizendo o que se passou. ${ }^{13}$

Assim, vemos que, para Luciano, o historiador deve ser uma espécie de filósofo cínico, livre e sem medo de ser sincero. Mais uma vez, é possível ligar essa passagem ao problema da adulação: se 0 historiador cometesse 0 erro de bajular os poderosos, estaria abdicando de sua liberdade e de sua autosuficiência.

Para todos os lados que se ol he, a adulação surge como um pecado a ser evitado. Como a adulação não devia ter espaço em uma obra de história, Luciano, para criticar esse vício, escreveu um panfleto com a forma de uma teoria da história. Em Como se deve escrever a história, os aspectos teóricos do tratado estão a serviço da intenção crítica; uma crítica surgida das necessidades políticas do presente. Se a circunstância da guerra e das histórias 
adulatórias que ela gerou não ocorresse, imagino que Luciano não teria escrito um tratado sobre a história.

Segundo Luciano, seus conselhos funcionavam "de uma maneira dupla"; ensinavam os historiadores "a escolher isso e evitar aquilo". Assim, ele começa a parte teórica de seu tratado catalogando "os vícios que seguem nos calcanhares dos historiadores medíocres" e ensinando, precisamente, como não se deve escrever a história.

Não à toa, dada a insistência de Luciano contra a adulação, a primeira distinção feita por ele é entre a história e o panegírico: com efeito, os historiadores "ignoram que não é um istmo estreito que delimita e separa a história do panegírico [enkómion], mas que há entre os dois uma grande muralha e, como dizem os músicos, uma distância de duas oitavas". ${ }^{14}$

Segundo Aristóteles, o elogio (épainos) e a censura (psógos) eram os assuntos do discurso epidítico, cujo objetivo era "o belo e o vergonhoso". 0 filósofo faz uma pequena diferenciação entre o panegírico (enkómion), que celebra os grandes feitos e as belas ações, e o elogio propriamente dito (épainos), que louva a maneira de ser, a grandeza de caráter, mas, não obstante, ambos eram classificados como parte da retórica epidítica.

A epídeixis (latim demonstratiuum) era um dos três tipos de discurso retórico, o discurso de exibição, o discurso "inútil" que não visava a nenhum processo específico de decisão; seu público deveria julgar apenas a habilidade, a força do orador. ${ }^{15} \mathrm{~N}$ ão se tratava, no entanto, de um objetivo puramente estético. $\mathrm{Na}$ Grécia, a estética era indissociável da ética e ambas caminhavam juntas o tempo todo como, por exemplo, na expressão grega que designava os "homens de bem": kaloi k'agathoí, "belos e bons". Assim, o epidítico, ao mesmo tempo em que era o gênero de discurso mais estético e, portanto, mais retórico (e mais sofístico), era também o gênero mais ético (e, portanto, mais filosófico).

Pode-se entender melhor a epídeixis por sua oposição à apódeixis, a prova retórica. ${ }^{16}$ Ambos os termos derivam do verbo 
deíknymi, "fazer ver", "mostrar". A preposição apó, no entanto, significa "desde", "a partir de", usada para exprimir a origem ou a causa de algo, enquanto a preposição epí significa "diante", "em presença de". Ou seja, enquanto a apódeixis era a "demonstração", no sentido quase científico da palavra, a epídeixis era a "mostração", o ato de apresentar-se ou apresentar algo (um discurso) diante de al guém, na presença de um público.

$\mathrm{N}$ a teoria aristotélica da retórica, um discurso deve possuir duas partes: "é necessário dizer do que se trata e então prová-lo [kaì tot' apodeîxai]". ${ }^{17}$ O u seja, a apódeixis era o próprio corpo do discurso, a prova, aquilo que deveria persuadir o público e, portanto, realizar a função retórica. M as a apódeixis era tanto a prova retórica como a demonstração científica: ambas complementavam a natureza ajudando a compreender os fenômenos, além de simples sensações, como símbolos do verdadeiro. Diferentemente do silogismo dialético ou do entimema retórico, em que se devia raciocinar a partir de opiniões, a apódeixis deveria partir de premissas verdadeiras, evidentes ou já demonstradas, e mostrar "a causa e o porquê".

Epídeixis, ao contrário, era o nome aplicado ao discurso dos sofistas; era a "demonstração" de seus poderes retóricos, ou melhor, a exibição pública da habilidade do sofista com as palavras. Professor itinerante de retórica, o sofista, ao chegar a uma nova cidade, em geral se dirigia à agorá e fazia um discurso (ou vários) no qual apresentava um único assunto: ele mesmo, sua capacidade como orador e, portanto, sua capacidade como professor de retórica.

Instala-se, assim, uma ruptura entre a retórica sofística (exibicionista) e a retórica aristotélica (dialética): enquanto a retórica filosófica de Aristóteles operava por demonstração, buscando a verdade, a retórica discursiva dos sofistas operava por argumentação, buscando um consenso. Na retórica sofística não há uma verdade da qual partir, pois há sempre, sobre todas as questões, dois discursos, duas opiniões, duas teses opostas: "em toda questão há dois lógos opostos entre si". O fragmento de Protágoras não deixa nenhuma saída teórica para o pensamento humano; ele se dá em um ritmo irrefreável de tese e antítese e 
não oferece nenhum critério absoluto que indique a maior veracidade de uma sobre a outra.

A posição de Luciano nessa guerra entre a filosofia e a sofística é clara: ele se posiciona contra a retórica vazia, simples discursos de aparato, sem conteúdo. Luciano começou sua carreira como orador e nunca deixou de sêlo, mas voltou 0 arsenal da retórica e da sofística contra os filósofos, sofistas, historiadores, gramáticos ou qualquer outro que considerasse hipócrita ou mentiroso.

A retórica, para Luciano, deveria ser uma retórica idealizada que seguisse "as pegadas de Demóstenes, Platão e alguns outros". M as a retórica dos antigos não existia mais; fora substituída por uma retórica das aparências, simples ornamento sem conteúdo ou utilidade. Restava apenas o "outro caminho", trilhado por "muita gente". ${ }^{18}$ Esse era 0 caminho da retórica "moderna", o caminho trilhado pelos "segundos" sofistas, biografados por Filóstrato, que visavam apenas a ganhos materiais.

J untamente com a retórica sem conteúdo, Luciano renega o prazer dos discursos e não Ihes permite um lugar na história. N o entanto, os maus historiadores achavam que era possível distinguir entre o prazeroso e o útil quando se tratava de história. "Por essa razão", prossegue, eles "trazem elogios para ela [a história], para dar prazer e divertimento aos leitores". ${ }^{19}$ Eles não sabem quão longe estão da verdade, pois "a história tem uma única tarefa e um único objetivo - o que é útil - e isso deriva somente da verdade". Por isso, os historiadores "não pode[m] admitir uma mentira, mesmo em pequenas doses", enquanto os oradores de sua época não se importavam em mentir para obter seus resultados: o prazer dos ouvintes, a fama e a fortuna resultantes do sucesso na carreira declamatória.

No entanto, Luciano concede que possa haver lugar para elogios em uma obra historiográfica, desde que eles sejam controlados pelo interesse da posteridade e pela utilidade. Tanto os elogios (épainoi) quanto as censuras (psógoi) deviam ser "cuidadosos e bem considerados, livres de contaminação pelos informantes, suportados pela evidência [metà apodé́xeon], curtos 
e não inoportunos, pois os envolvidos não estão sendo acusados no tribunal". ${ }^{20}$

Ou seja, há um lugar para o elogio na historiografia, desde que "seja feito na hora certa e que se mantenha dentro de limites razoáveis". ${ }^{21} 0$ grande problema, portanto, não parece ser 0 elogio em si, mas o exagero do seu uso. De fato, o uso de elogios exagerados na história nem ao menos dá prazer aos ouvintes. Pois o elogio só é prazeroso para uma pessoa, o elogiado. Se os historiadores não sabem como fazê-lo e exageram no elogio, mesmo o elogiado irá "virar suas costas a eles" e eles não conseguirão "o que mais queriam", as recompensas materiais dadas aos bajuladores.

Além disso, quando Luciano diz que o elogio na historiografia deve se basear em evidências (metà apodeíxeon), mostra a antiga filiação daquela com a verdade e afasta-a ainda mais da retórica epidítica. Com efeito, assim como a apódeixis da retórica aristotélica, a história deveria partir de fatos verdadeiros e mostrar sua causa. Isto fica bem claro no prefácio de H eródoto:

[...] esta é a demonstração da investigação [historíes apódexis] de Heródoto de Halicarnasso, para que nem as coisas feitas pelo homem se apaguem com o tempo, nem que as grandes e maravilhosas obras, algumas realizadas [apodechthénta, i.e., demonstradas] pelos gregos, outras pelos bárbaros, se tornem inglórias, tanto em outros respeitos, quanto sobre a causa [aitíen] pela qual eles moveram guerra uns contra os outros.

Ou seja, Heródoto partiu de um acontecimento - a guerra contra os persas - e tentou demonstrar (apódeixis) sua causa (aitía), mediante um procedimento baseado na investigação (historía).

O uso de procedimentos retóricos na elaboração da narrativa histórica era absolutamente natural e necessário para Luciano - que, não podemos esquecer, teve ampla formação retórica. A "retórica historiográfica" proposta por Luciano (e levada a cabo por Heródoto e Tucídides), no entanto, se afastava da retórica exibicionista dos sofistas de seu tempo e se 
aproximava da retórica filosófica de Aristóteles. Tratava-se de partir dos acontecimentos, verdadeiros e evidentes, e demonstrálos. Mas nunca se poderia esquecer que a história "tem uma única tarefa e um único objetivo - a utilidade - e isso deriva apenas da verdade". ${ }^{23}$ Todos os procedimentos retóricos utilizados na elaboração historiográfica deveriam estar sujeitos a isso.

Por fim, creio que vale a pena examinarmos uma pequena metáfora utilizada por Luciano em seu manual. Segundo o sírio, o historiador deve deixar que sua inteligência seja "semelhante a um espelho impoluto, brilhante, preciso quanto a seu centro - e, qualquer que seja a forma dos fatos que recebe, assim os mostre, sem nenhuma distorção, diferença de cor ou alteração de aspecto". ${ }^{24}$

A referência à mente do historiador como um espelho que reflete os fatos é bastante interessante. Pois o espelho, por mais centrado e impoluto que seja, reflete uma imagem parecida com a original, mas que guarda algumas diferenças dessa. A mais evidente dessas diferenças é a inversão que se efetua na superfície do espelho entre direita e esquerda - e os antigos jamais deixaram de percebê-la. Platão, por exemplo, cita diversas vezes esse fenômeno.

Aristóteles, por sua vez, em seu tratado sobre as cores, também chama a atenção para a diferença de tom entre o modelo e seu reflexo: "as imagens que se refletem na água parecem mais aquosas, e aquelas que se formam nos espelhos têm cores parecidas àquelas dos espelhos". O u seja, ao duplicar a imagem, 0 espelho modifica a aparência do original, juntando-Ihe alguma coisa de sua própria aparência, um ligeiro bronze metálico ou uma textura aquosa, que são a marca da mistura e, por conseqüência, da diferença, do afastamento. Plutarco também chama a atenção para as contribuições do espelho à formação do reflexo: a Pítia de Delfos, espelho de Apolo, por mais dócil e fiel que seja, modifica um pouco, por sua natureza, a qualidade daquilo que recebe do deus. 
Isso poderia significar que o historiador sempre vai acrescentar algo aos fatos, malgrado sua precisão e imparcialidade? Talvez. Mas creio que isso seria ler Luciano pensando em Hayden White. Luciano, como todos os antigos, acreditava na possibilidade de "narrar a história tal como ela aconteceu". ${ }^{25}$ Além do que, não podemos esquecer que 0 espelho criticado por Platão e Aristóteles é o objeto, o disco metálico que reflete imagens. Na literatura grega, no entanto, o espelho aparece quase sempre com um sentido figurado. E esse sentido sempre se reflete sobre o plano moral.

O tempo é uma dessas metáforas do espelho. Ele é visto como o revelador dos erros, dos fatos obscuros que só se tornam conhecidos com a distância temporal:

Q uanto aos perversos, o próprio tempo os revela quando chega o momento certo, apresentando-Ihes o seu espelho como às moças vaidosas. ${ }^{26}$

Ou seja, o tempo revela a perversidade colocando-a em plena luz. 0 espelho do tempo age, portanto, como um projetor que vai buscar os indivíduos perversos na obscuridade e no esquecimento onde se encontram. E o receptor dessa revelação não é, como no caso do espelho metálico da beleza das moças, o próprio perverso, mas um espectador coletivo: a opinião pública, diante da qual aquele indivíduo é exibido. Ou seja, na metáfora temporal, o espelho revela aquilo que, sem ele, escaparia aos olhares. Ele éa ferramenta que faz visível.

Além do tempo, o olho e o rosto são espelhos evidentes: "acredito ser incorreto dizer que o espírito é absolutamente invisível, ele transparece exatamente no espelho do rosto". ${ }^{27}$ Esses espelhos, no entanto, não limitam sua atividade a refletir para outrem a imagem recebida. Vão buscar nas profundezas as verdades que é necessário fazer aflorar: "pois os detalhes do caráter dos homens podem ser desnudados pela visão [... ]; a partir disso, os sábios, instruídos pela natureza, vêem os espíritos dos homens como uma imagem em um espelho". ${ }^{28}$

A própria concepção grega de homem refletia essa idéia da essência espelhada no rosto: prósopon, que significava "rosto" em 
Homero, "expressão do rosto" ou "atitude" em Ésquilo, "personagem [de teatro]" no século IV, e a partir da época helenística, "pessoa", tinha o sentido literal de 'aquilo que está diante dos olhos [de outrem]'. Ou seja, nenhum ser humano se definia pela individualidade de seus traços, pelo que compusesse sua figura; mas seu rosto, sua personalidade, sua alma, sua pessoa não existiam a não ser sob a vista de um outro.

Também o vinho é visto como um espelho: "o espelho da alma, assim como o bronze [i.e., o espelho metálico] o é da beleza" ${ }^{29}$ Teógnis nos explica:

É ao fogo que os conhecedores testam o ouro e a prata; é o vinho que mostra o que é o espírito de um homem, mesmo de um homem muito sensato, pois quando ele gosta de beber sem medida, beberá a um ponto onde mesmo o sábio pode se cobrir de vergonha. ${ }^{30}$

0 processo visual desencadeado pelo vinho aparece na expressão utilizada por Alceu - "o vinho é para os humanos um espelho [díoptron]". ${ }^{31}$ A palavra díoptron evoca uma visão penetrante, que vai buscar seu objeto depois ou abaixo do líquido espelhado; ou então, inversamente, uma imagem que surge das profundezas para eclodir na superfície. Assim, a verdadeira alma do homem surgiria como uma imagem na superfície do vinho que ele beber.

A imagem do vinho remete à da embriaguez, que libera a palavra e leva ao excesso: "quando uma cidade democrática, sedenta de liberdade [eleutherías], tem à sua frente maus servidores, ela não tem mais medida e se inebria dela pura [akrátou]". ${ }^{32}$ Segundo Platão, assim como o vinho puro recebe uma parte de água para evitar o excesso da embriaguez, a liberdade deve ser limitada pelas instituições políticas ou pelos governantes e, por isso, não pode ser uma liberdade pura.

0 historiador, tal como a cidade democrática, também deve evitar o excesso de liberdade para fugir à embriaguez e não transformar a história em poesia. Pois Luciano adverte: é "uma grande falha [...] trazer os embelezamentos da poesia para a história - o mito, o elogio e os exageros de ambos". Os maus 
historiadores não percebem que, "da arte poética e dos poemas as intenções são umas e os cânones próprios; já os da história são outros. Na poesia há pura liberdade [ákratos he eleuthería] e uma só lei - a opinião do poeta".

A liberdade pura que embriaga os ouvintes é a norma na poesia, mas não na história. Assim como o homem sábio deve evitar 0 vinho puro, não misturado, o historiador deve evitar tomar licenças em excesso em seu trabalho, pois somente o poeta tem direito à liberdade pura. Assim como os governantes democratas devem cercear a liberdade do povo para evitar os excessos, a verdade cerceia a liberdade do historiador, que deve sacrificar tudo a ela:

A única tarefa do historiador é contar o que aconteceu. E ele não pode fazêlo enquanto tiver medo de Artaxerxes quando é seu médico ou espera ganhar uma caftan púrpura, um colar de ouro ou um cavalo de Nicéia como recompensa pelos elogios em sua obra. Nem Xenofonte, historiador justo, nem Tucídides fariam isso. Ao contrário, mesmo se ele pessoalmente odeia algumas pessoas, irá pensar primeiro no interesse público e considerar a verdade mais digna do que a inimizade e se tem um amigo, não irá perdoá-lo se ele errar. Isso, como eu disse, é a única coisa peculiar à historiografia e somente à verdade deve ser oferecido sacrifício. Quando um homem vai escrever história, deve ignorar todo o resto. ${ }^{34}$

Vê-se novamente nessa passagem a questão da verdade da historiografia oposta à adulação dos poderosos. Como já dissemos antes, essa é a oposição central em Como se deve escrever a história. Para retomar pela última vez essa questão da adulação, cumpre lembrar que o adulador também aparece como uma metáfora do espelho:

Não se verá jamais um adulador mostrar originalidade, nem se ressentir de sentimentos pessoais de amor, de ódio, de prazer ou de tristeza, mas ver-seá receber, como um espelho, a imagem das paixões, das existências, ou de movimentos que lhe são estranhos. ${ }^{35}$ 
O adulador, na ânsia por agradar, se torna um espelho daquele a quem adula. Anula-se para se tornar o que o outro desejaria que ele fosse.

Ao utilizar o espelho como metáfora para a mente do historiador, creio que Luciano estava, como nos demais exemplos citados, ressaltando o aspecto moral e ético da história. Pois se o espelho reflete tanto o certo quanto o errado, é tarefa do historiador refletir, dentre as imagens que sua mente vê nos acontecimentos, aquelas que são justas. Se o historiador pretende que sua história seja justa, se pretende que sua obra tenha al guma utilidade para o futuro e possa ser, como Tucídides "legislou", "um tesouro [ktêmá] para sempre", ${ }^{36}$ ele não pode dar espaço para a adulação ou para os excessos da poesia. Sua obra deve ser uma história verdadeira e digna de confiança, que ensine e eduque os homens do futuro com os acontecimentos do presente, para que, quando os acontecimentos, devido à natureza humana, venham a se repetir, eles estejam preparados para agir melhor.

LEME LOPES, André. Morality and justice in ancient history: Luciano de Samósata's "manual" on historiography. História, São Paulo, v.24, n.2, p.187-205, 2005.

ABSTRACT: Luciano de Samosata's How history should be written is the only known treatise on history from Antiquity. It was written in the context of the "historical" production spawned by Lucio Vero' Parthian wars (second half of the second century A.D.). To underline the moral and political position of the historian - who must, above all, be just -, Luciano criticizes these flattering narratives and presents Thucydides as the model historian.

KEYWORDS: Greek historiography; theory of history; Luciano de Samósata.

NOTAS 
* Professor de Teoria da História e Historiografia no Depto. de História da Universidade Estadual de Goiás - UEG, Formosa, GO. CEP 73802-000. email: a.lemelopes@gmail.com

${ }^{1}$ Como se deve escrever a história, 2. Luciano se refere à guerra iniciada pelo rei parto Vologésio IV na primavera do ano 162 e vencida pelo co-imperador Lúcio Vero quatro anos depois (o triunfo foi celebrado em 12 de outubro de 166). A edição consultada para as obras de Luciano é Lucian in eight volumes. Londres, Cambridge, Mass.: William Heinemann, Harvard University, 19131959; as traduções, exceto quando indicado, são minhas.

2 ANDERSON, Graham. Lucian: a sophist's sophist. Yale Classical Studies, Cambridge, n.27, p.68, 1982. Vide BRANDÃO, Jacyntho Lins. A poética do hipocentauro: literatura, sociedade e discurso ficcional em Luciano de Samósata. Belo Horizonte: UFMG, 2001, p.36, n.40.

${ }^{3}$ Como se deve escrever a história, p.14.

${ }^{4}$ Como se deve escrever a história, p.63. É interessante observar a função sintática da expressão "com o verdadeiro [sỳn tôi alethể]", um dativo de instrumento. Vide BRANDÃO, Jacyntho Lins. Comment on doit écrire l'histoire. Transcrição de três seminários apresentados em Paris, 2001, seminário I, p.11 (mimeo).

${ }^{5}$ Como se deve escrever a história, p.7.

6 CANFORA, Luciano. Teorie e tecnica della storiografia classica: Luciano, Plutarco, Dionigi, anonimo su Tucidide. 2.ed. Roma, Bari: Laterza, 1996, p.14.

FLÁVIO JOSEFO, Guerra judaica, I, prefácio, p.1-2. Vide BRANDÃO, Jacyntho Lins. Comment on doit écrire l'histoire. Transcrição de três seminários apresentados em Paris, 2001, seminário I, p. 29 (mimeo).

${ }^{8}$ Como se deve escrever a história, p.63.

${ }^{9}$ Como se deve escrever a história, p.4-5.

${ }^{10}$ Como se deve escrever a história, p.63.

${ }^{11}$ O leilão dos filósofos, p.8.

${ }^{12}$ Diálogos dos mortos, XI, p.3.

${ }^{13}$ Como se deve escrever a história, p.41.

${ }^{14}$ Como se deve escrever a história, p.7.

15 Vide ARISTÓTELES, Retórica I, 1358b, p.7-8: "há, portanto, necessariamente três gêneros de discursos na retórica: o deliberativo [symbouleutikón], o judiciário [dikanikón], o epidítico [epideiktikón]”. A mesma classificação aparece em latim, por exemplo, em Retórica a Herênio I, 2: "existem três gêneros de causas dos quais o orador deve tratar: o gênero demonstrativo [demonstratiuum], o deliberativo [deliberatiuum] e o judiciário [iudiciale]" (Retórica a Herênio foi, por muito tempo, atribuída a Cícero. Hoje é referida como de autoria desconhecida e especula-se que, talvez, tenha sido obra de Cornifício, citado por Quintiliano como autor de uma Ars Rhetorica - a 
esse respeito, ver TRINGALI, Dante. Introdução à retórica (a retórica como crítica literária). São Paulo: Duas Cidades, 1988, p.41.

${ }^{16}$ De uma maneira geral, sigo aqui as análises de CASSIN, Barbara. Dizer o que se vê, fazer o que se diz: a retórica de Aristóteles e a dos sofistas. In:__. Ensaios sofísticos. São Paulo: Siciliano, 1990, p.234-239; e CASSIN, Barbara. Consenso e criação de valores - o que é um elogio?. In: CASSIN, Barbara, LORAUX, Nicole, PESCHANSKI, Catherine. Gregos, bárbaros, estrangeiros: a cidade e seus outros. Rio de Janeiro: Ed. 34, 1993, p.38-39.

${ }^{17}$ Retórica III, 13, 1414 , p.33-34.

${ }^{18}$ Mestre de retórica, p.9-11.

${ }^{19}$ Como se deve escrever a história, p.9. Em Sobre a dança, p.34, Luciano diz que seu objetivo não é fazer uma história da dança mas, apenas, elogiá-la como ela existia na época. É verdade que o verbo por ele utilizado é genealogền, 'fazer uma genealogia', e não historeîn, mas, ainda assim, o contraste entre o elogio e um relato do passado se coloca. Vide GEORGIADOU, Aristoula, LARMOUR, David H. J. Lucian and historiography: De historia conscribenda and Verae historiae. In: HAASE, Wolfgang, TEMPORINI, Hildegard (eds.). Aufstieg und Niedergang der Römischen Welt: Geschichte und Kultur Roms im Spiegel der neueren Forschung, parte II: Principat, v.34: Sprache und Literatur: einzelne Autoren seit der hadrianischen Zeit und allgemeines zur Literatur des 2. und 3. Jahrhunderts. Berlim, Nova Iorque: Walter de Gruyter, 1994, v.2, p.1455.

${ }^{20}$ Como se deve escrever a história, p.59.

${ }^{21}$ Como se deve escrever a história, p.9.

${ }^{22}$ HERÓDOTO, História I. 1 segundo a tradução de MOLES, J.L. Truth and untruth in Herodotus and Thucydides. In: GILL, Christopher, WISEMAN, T.P. (eds.). Lies and fiction in the ancient world. Austin: University of Texas, 1993, p.88-121.

${ }^{23}$ Como se deve escrever a história, p.9.

${ }^{24}$ Como se deve escrever a história, p.51.

25 Apesar da Fama, divindade de mil bocas, essa frase foi escrita mil e quinhentos anos antes de Ranke por Luciano em Como se deve escrever a história, p.39. Vide VEYNE, Paul. Acreditaram os gregos nos seus mitos? Lisboa: Edições 70, 1987, p.130, n.1.

${ }^{26}$ EURÍPIDES. Hipólito, p.429-430, segundo a tradução de KURY, Mário da Gama. Eurípides: Medéia - Hipólito - As troianas. Rio de Janeiro: Jorge Zahar, 1991 , p.110.

${ }^{27}$ AQUILES TÁCIO. As aventuras de Leucipe e Clitofonte VI. Segundo a tradução de GRIMAL, Pierre (ed.). Romans grecs E latins. Paris: Gallimard, 1958, p.978 (Bibliothèque de la Pléiade). 
${ }^{28}$ FILÓSTRATO. Vida de Apolônio de Tiana II, 30. Segundo a tradução de GRIMAL, Pierre (ed.). Romans grecs E latins. Paris: Gallimard, 1958, p.1094 (Bibliothèque de la Pléiade).

${ }^{29}$ ÉSQUILO. fragmento 393. In: NAUCK, A., SNELL, B. Tragicorum graecorum fragmenta.

${ }^{30}$ TEÓGNIS. Poemas elegíacos, p.499-502. Segundo a tradução de CARRIÈRE, Jean. Théognis. Poèmes élégiaques. Paris: Les Belles Lettres, 1948.

${ }^{31}$ Apud FRONTISI-DUCROUX, Françoise. L'oeil et le miroir. In: FRONTISIDUCROUX, Françoise; VERNANT, Jean-Pierre. Dans l'oeil du miroir. Paris: Odile Jacob, 1997, p.114.

32 PLATÃO. República VIII, p.562c-d. Segundo a tradução de BRANDÃO, Jacyntho Lins. Comment on doit écrire l'histoire. Transcrição de três seminários apresentados em Paris, 2001, seminário III, p.15 (mimeo). A palavra akrátou remete ao vinho não misturado com água na cratera (kratér).

${ }^{33}$ Como se deve escrever a história, p.8.

${ }^{34}$ Como se deve escrever a história, p.39-40.

${ }^{35}$ PLUTARCO. Como distinguir um adulador de um amigo [Moralia], p.53a. Apud FRONTISI-DUCROUX, Françoise. L'oeil et le miroir. In: FRONTISIDUCROUX, Françoise; VERNANT, Jean-Pierre. Dans l'oeil du miroir. Paris: Odile Jacob, 1997, p.125.

${ }^{36}$ Como se deve escrever a história, p.42, seguindo TUCÍDIDES I, p.22.

Artigo recebido em 06/2006. Aprovado em 08/2006 